\title{
Halorhabdus utahensis gen. nov., sp. nov., an aerobic, extremely halophilic member of the Archaea from Great Salt Lake, Utah
}

\author{
Michael Wainø, ${ }^{1}$ B. J. Tindall ${ }^{2}$ and Kjeld Ingvorsen ${ }^{1}$
}

Author for correspondence: Kjeld Ingvorsen. Tel: +458942 3245. Fax: +458612 7191. e-mail: kjeld.ingvorsen@biology.aau.dk

1 Institute of Biological Sciences, Department of Microbial Ecology, University of Århus, Ny Munkegade, Building 540, 8000 Århus C, Denmark

2 DSMZ-Deutsche Sammlung von Mikroorganismen und Zellkulturen $\mathrm{GmbH}$, Mascheroder Weg $1 \mathrm{~b}$, D-38124 Braunschweig, Germany

\begin{abstract}
Strain AX-2 ${ }^{\top}(T=$ type strain) was isolated from sediment of Great Salt Lake, Utah, USA. Optimal salinity for growth was $27 \%(w / v) ~ N a C l$ and only a few carbohydrates supported growth of the strain. Strain AX-2 ${ }^{\top}$ did not grow on complex substrates such as yeast extract or peptone. 16S rRNA analysis revealed that strain $\mathrm{AX}-2^{\top}$ was a member of the phyletic group defined by the family Halobacteriaceae, but there was a low degree of similarity to other members of this family. The polar lipid composition comprising phosphatidyl glycerol, the methylated derivative of diphosphatidyl glycerol, triglycosyl diethers and sulfated triglycosyl diethers, but not phosphatidyl glycerosulfate, was not identical to that of any other aerobic, halophilic species. On the basis of the data presented, it is proposed that strain AX-2 ${ }^{\top}$ should be placed in a new taxon, for which the name Halorhabdus utahensis is appropriate. The type strain is strain AX-2 ${ }^{\top}$ (= DSM 12940').
\end{abstract}

Keywords: Halorhabdus utahensis, Archaea, extremely halophilic, taxonomy

\section{INTRODUCTION}

The increasing interest, in recent years, in microorganisms from hypersaline environments has led to the discovery of several new species and genera belonging to the Bacteria and the Archaea. Within the family Halobacteriaceae, comprising the aerobic, extremely halophilic members of the Archaea, there are, at the time of writing, 10 described genera whose names have been validly published: Haloarcula, Halobacterium, Halobaculum, Halococcus, Haloferax, Halorubrum, Natrialba, Natronobacterium, Natronococcus and Natronomonas.

Strains of aerobic, extremely halophilic members of the Archaea have been isolated from various hypersaline environments such as hypersaline lakes (e.g. Franzmann et al., 1988; Oren et al., 1995), soda lakes (e.g. Soliman \& Trüper, 1982; Tindall et al., 1984), solar salterns (e.g. Nuttall \& Dyall-Smith, 1993; Juez et al., 1986; Ihara et al., 1997), saline soils (e.g. Kobayashi et al., 1992; Zvyagintseva \& Tarasov, 1987) or salt mines (e.g. Denner et al., 1994; Norton et al., 1993).

Abbreviations: PG, phosphatidyl glycerol; PHB, poly- $\beta$-hydroxybutyrate; MePGP, methylated-phosphatidyl glycerophosphate; S-TGD, sulfated triglycosyl glycolipid; TGD, triglycosyl glycolipid.
During a preliminary study of the distribution of halophilic members of the Bacteria and the Archaea in Great Salt Lake, UT, USA, three extremely halophilic strains were isolated. One strain, designated strain $\mathrm{AX}-2^{\mathrm{T}}$, was the subject of the current taxonomic study, while the other two strains were shown not to be taxonomically related to strain AX-2. Physiologically, strain $\mathrm{AX}-2^{\mathrm{T}}$ only used a limited range of substrates for growth and was unique in its inability to utilize yeast extract or peptone for growth. Strain AX-2 contained MK-8, MK-8(VIII- $\left.\mathrm{H}_{2}\right)$ and diether-linked lipids, features common to all members of the family Halobacteriaceae. The major diether lipids present were diphytanyl derivatives $\left(\mathrm{C}_{20}, \mathrm{C}_{20}\right)$. The polar lipids present comprised the corresponding diether derivatives of phosphatidyl glycerol (PG), methylatedphosphatidyl glycerophosphate (MePGP), a triglycosyl glycolipid (TGD) and a sulfated triglycosyl glycolipid (S-TGD). This composition indicates that strain $\mathrm{AX}-2^{\mathrm{T}}$ is a member of the family Halobacteriaceae, but is chemically distinctive and constitutes a member of a novel taxon within this family. Consequently, we consider that strain $\mathrm{AX}-2^{\mathrm{T}}$, on the basis of the biochemical and physiological properties, the chemical data and the 16S rDNA sequence, constitutes a new species within a new genus, for which we propose the name Halorhabdus utahensis gen. nov., sp. nov. 


\section{METHODS}

Isolation procedure. Strain $\mathrm{AX}-2^{\mathrm{T}}$ was isolated from a sediment sample collected from the southern arm of Great Salt Lake, UT, USA. Approximately $2 \mathrm{~g}$ of sample was used to inoculate $20 \mathrm{ml}$ enrichment medium (EX-medium) containing the following $\left(\mathrm{g}^{-1}\right)$ : $\mathrm{NaCl}, 220 ; \mathrm{NaBr}, 0 \cdot 1$; $\mathrm{MgSO}_{4} .7 \mathrm{H}_{2} \mathrm{O}, 20 ; \mathrm{KCl}, 5 ; \mathrm{NH}_{4} \mathrm{Cl}, 2 ; \mathrm{NaHCO}_{3}, 0 \cdot 2$; $\mathrm{KH}_{2} \mathrm{PO}_{4}, 0.5$; yeast extract (Difco), 2; trypticase peptone (BBL), 1; and trace-metal solution (TMS 3), $2 \mathrm{ml}$ (Ingvorsen \& Jørgensen, 1984). The $\mathrm{pH}$ was adjusted to $7 \cdot 6$ with $5 \mathrm{M}$ $\mathrm{NaOH}$ and the medium was autoclaved for $20 \mathrm{~min}$ at $121^{\circ} \mathrm{C}$. After sterilization and cooling to $5{ }^{\circ} \mathrm{C}, 5 \mathrm{ml}$ sterile $\mathrm{CaCl}_{2}$ solution $\left(\mathrm{CaCl}_{2} \cdot 6 \mathrm{H}_{2} \mathrm{O}, 100 \mathrm{~g} \mathrm{l}^{-1}\right)$ and $2 \mathrm{ml}$ sterile $\mathrm{FeCl}_{2} /$ $\mathrm{MnCl}_{2}$ solution $\left(\mathrm{FeCl}_{2} \cdot 4 \mathrm{H}_{2} \mathrm{O}, 20 \mathrm{~g} \mathrm{l}^{-1}+\mathrm{MnCl}_{2} \cdot 4 \mathrm{H}_{2} \mathrm{O}, 20 \mathrm{~g}\right.$ $\mathrm{1}^{-1}$ ) were added. Sterile solutions of streptomycin, tetracycline and chloramphenicol were also added at final concentrations of 100,20 and $20 \mathrm{mg}^{-1}$, respectively. Glucose was added to EX-medium as a carbon substrate at a final concentration of $2 \mathrm{~g} \mathrm{l}^{-1}$. A $0 \cdot 1 \mathrm{ml}$ aliquot from a serial dilution of the enrichment culture was spread on solid EXmedium (15 $\mathrm{g}^{-1}$ agar) containing $2 \mathrm{~g}$ glucose $1^{-1}$. After 3 weeks incubation at $30^{\circ} \mathrm{C}$, several red-pigmented colonies appeared on the agar plates. Pure cultures were obtained by restreaking several times; one colony was picked to serve as the strain for characterization.

Growth media. The culture medium (27\% Tris 10$)$ used for maintenance of strain AX-2 contained the following $\left(\mathrm{g}^{-1}\right)$ : $\mathrm{NaCl}, 270 ; \mathrm{NaBr}, 0 \cdot 1 ; \mathrm{MgSO}_{4} .7 \mathrm{H}_{2} \mathrm{O}, 20 ; \mathrm{KCl}, 5 ; \mathrm{NH}_{4} \mathrm{Cl}, 2$; Tris/HCl, 12; yeast extract (Difco), 1; and trace-metal solution (TMS 3), $2 \mathrm{ml}$. The $\mathrm{pH}$ was adjusted to $7 \cdot 6$ with $5 \mathrm{M}$ $\mathrm{NaOH}$ and the medium was autoclaved for 20 min at $121^{\circ} \mathrm{C}$. After sterilization and cooling to $5^{\circ} \mathrm{C}, 2.5 \mathrm{ml}$ sterile $\mathrm{KH}_{2} \mathrm{PO}_{4}$ solution $\left(50 \mathrm{~g} \mathrm{l}^{-1}\right), 0 \cdot 5 \mathrm{ml}$ sterile $\mathrm{CaCl}_{2} \cdot 6 \mathrm{H}_{2} \mathrm{O}$ solution $(100 \mathrm{~g}$ $1^{-1}$ ) and $0 \cdot 25 \mathrm{ml}$ sterile $\mathrm{FeCl}_{2} \cdot 4 \mathrm{H}_{2} \mathrm{O} / \mathrm{MnCl}_{2} \cdot 4 \mathrm{H}_{2} \mathrm{O}$ solution (20 $\mathrm{g} \mathrm{l}^{-1}$ each) were added. Agar plates were prepared by using Tris 10 medium containing $20 \% \mathrm{NaCl}$ and $15 \mathrm{~g}$ agar $1^{-1}$. Glucose $\left(2 \mathrm{~g} \mathrm{l}^{-1}\right)$ served as the carbon substrate in both liquid and solid medium. Cell material for lipid analysis was grown on GSL-2 medium containing $20 \%$ (w/v) $\mathrm{NaCl}$ (Wainø et al., 1999) at $37^{\circ} \mathrm{C}$ with shaking. Cells were harvested by centrifugation, freeze-dried and stored at $-20{ }^{\circ} \mathrm{C}$ before analysis.

Culture maintenance and morphological tests. The isolate was grown at $30{ }^{\circ} \mathrm{C}$ and routinely transferred to fresh medium or kept on agar plates at $5^{\circ} \mathrm{C}$. Staining of flagella and endospores was performed according to the methods of Leiffson and Schaeffer-Fulton, respectively (Gerhardt et al., 1981). The morphology of colonies was observed on $20 \%$ Tris 10 agar plates after 3-6 weeks growth.

Physiological and biochemical tests. Growth in a defined medium containing $20 \%(\mathrm{w} / \mathrm{v}) \mathrm{NaCl}$ was tested in Tris 9 medium. This medium was prepared by replacing the yeast extract from the Tris 10 medium with $1 \mathrm{ml}$ vitamin solution (Balch et al., 1979). The effect of $\mathrm{NaCl}$ was determined in both Tris $9(0-30 \% \mathrm{NaCl})$ and Tris $10(6-30 \% \mathrm{NaCl})$ medium at $30{ }^{\circ} \mathrm{C}$ using $0.2 \%(\mathrm{w} / \mathrm{v})$ glucose as substrate. The effect of $\mathrm{MgSO}_{4}$ was tested in $27 \%$ Tris 10 medium at $30{ }^{\circ} \mathrm{C}$ using $0.4 \%(\mathrm{w} / \mathrm{v})$ glucose as substrate. Growth at various temperatures and $\mathrm{pH}$ values was also determined in $27 \%$ Tris 10 containing $0 \cdot 2 \%(\mathrm{w} / \mathrm{v})$ and $0 \cdot 1 \%(\mathrm{w} / \mathrm{v})$ glucose, respectively. Anaerobic growth was tested in both complex (AM) and defined medium (AM 2). AM and AM 2 media were prepared by replacing the $\mathrm{MgSO}_{4} \cdot 7 \mathrm{H}_{2} \mathrm{O}$ content of the Tris 10 and Tris 9 media, respectively, with an equimolar amount of $\mathrm{MgCl}_{2} \cdot 6 \mathrm{H}_{2} \mathrm{O}$. Glucose, acetate or ethanol was added as a potential substrate, while $\mathrm{S}^{\circ}, \mathrm{SO}_{4}^{2-}, \mathrm{S}_{2} \mathrm{O}_{3}^{2-}$ or $\mathrm{NO}_{3}^{-}$ was added as a potential electron acceptor. Fermentation of glucose was tested in AM 2 medium without added electron acceptors. Growth on the following substrates was tested at $0.2 \%$ and $0.5 \%(\mathrm{w} / \mathrm{v})$ substrate concentrations in $20 \%$ Tris 10 medium: glucose, xylose, fructose, amylose, arabinose, galactose, lactose, maltose, sucrose, Na-acetate, $\mathrm{Na}$-citrate, Na-formiate, Na-glucuronate, Na-lactate, $\mathrm{Na}$ pyruvate, $N$-acetyl-glucosamine, L-alanine, betaine, L-lysine, phenylalanine, L-proline, L-serine, acetamide, ethanol, glycerol, methanol, sorbitol, glycogen, peptone, yeast extract, starch, casein, gelatin and Tween 80 . All growth tests were performed at $30^{\circ} \mathrm{C}$, except for temperature tests, and growth was determined by measuring the optical density of the culture at $600 \mathrm{~nm}$.

Gram staining was performed using the method of Dussault (1955). The presence of catalase and of oxidase were tested according to Gerhardt et al. (1981). Methyl red and Voges-Proskauer tests were carried out as described by Gerhardt et al. (1981) but modified by adding $27 \%(\mathrm{w} / \mathrm{v})$ $\mathrm{NaCl}, 2 \%$ (w/v) $\mathrm{MgSO}_{4} .7 \mathrm{H}_{2} \mathrm{O}, 0 \cdot 5 \%$ (w/v) $\mathrm{KCl}$ and $0.25 \%$ yeast extract to the test medium. Arginine dihydrolase, lysine and ornithine decarboxylase were tested as described by Skerman (1967) but modified by adding $27 \%$ (w/v) $\mathrm{NaCl}, 2 \%(\mathrm{w} / \mathrm{v}) \mathrm{MgCl}_{2} \cdot 6 \mathrm{H}_{2} \mathrm{O}$ and $0 \cdot 5 \%(\mathrm{w} / \mathrm{v}) \mathrm{KCl}$ to the test medium. The production of indole, urease and tryptophan deaminase, as well as the utilization of citrate, were tested using an API-20 E test (20100; bioMérieux). Hydrolysis of aesculin and gelatin were tested using an API-20 $\mathrm{NE}$ test (20050; bioMérieux). Reduction of $\mathrm{NO}_{3}^{-}$to $\mathrm{NO}_{2}^{-}$or $\mathrm{N}_{2}$ and gas production from sugars were tested according to Gerhardt et al. (1981). Reduction of $\mathrm{NO}_{3}^{-}$was tested using $20 \%$ Tris 10 medium containing $0 \cdot 1 \%$ (w/v) $\mathrm{KNO}_{3}$ and $0 \cdot 1 \%(\mathrm{w} / \mathrm{v})$ glucose, while gas production from sugars was tested using $20 \%$ Tris 9 medium containing $0.5 \%(\mathrm{w} / \mathrm{v})$ glucose. In both cases, test tubes contained inverted Durham vials and the medium was overlaid with mineral oil. The production of hydrogen sulfide was tested as described by Cord-Ruwisch (1985) on aliquots from anaerobic growth tests. The determination of antibiotic susceptibility was performed by spreading bacterial suspensions on solid EXmedium containing $2 \mathrm{~g}^{-1}$ glucose and applying NeoSensitabs (DK; Rosco Diagnostica). Inhibition zones were measured after $18 \mathrm{~d}$ growth and interpreted according to the manufacturer's manual. The production of poly- $\beta$-hydroxybutyrate (PHB) was examined by growing bacteria in a $\mathrm{C}$ rich, N- and P-limited medium as recommended by Fernandez-Castillo et al. (1986) and Lillo \& RodriguezValera (1990). The PHB-medium was prepared by omitting $\mathrm{KH}_{2} \mathrm{PO}_{4}$ from the $20 \%$ Tris 10 medium and reducing the $\mathrm{NH}_{4} \mathrm{Cl}$ content to $0.05 \mathrm{~g} \mathrm{l}^{-1}$. Furthermore, $1 \%(\mathrm{w} / \mathrm{v})$ glucose was added as substrate. The presence of PHB was tested for according to Gerhardt et al. (1981).

Electron microscopy. Exponentially growing cells were harvested and fixed in cold $2.5 \%$ glutaraldehyde $(0 \cdot 1 \mathrm{M}$ cacodylate buffer, $\mathrm{pH} 7 \cdot 2)$. After $1 \mathrm{~h}$ fixation, the cells were washed three times in cacodylate buffer and subsequently postfixed for $1 \mathrm{~h}$ in $1 \%$ osmium tetroxide buffered with veronal acetate buffer $(\mathrm{pH} \mathrm{7 \cdot 2)}$. The pellet was dehydrated with propanol and embedded in TAAB 812 resin (TAAB Laboratories equipment). Thin sections were prepared with an Ultramicrotome (LKB Instruments) and poststained with uranyl acetate and lead citrate. Finally, the sections were examined in a Phillips CM-20 electron microscope operated at $120 \mathrm{kV}$.

Detection of diether lipids. Diether lipids were released from 
$100 \mathrm{mg}$ freeze-dried cells using comparatively mild hydrolytic methods that did not lead to significant cleavage of hydroxylated isoprenoid ether lipids (B. J. Tindall, unpublished results; Eikel \& Sprott, 1992). The ether lipids were analysed using silica-gel TLC (art. no. 818135; MachereyNagel) with either double development in hexane/tertbutylmethylether $(4: 1, \mathrm{v} / \mathrm{v})$ (detection of diether lipids) or in hexane/tert-butylmethylether/acetic acid $(25: 25: 1$, by vol.) (detection of diether and tetraether lipids). Lipid material was visualized using dodecamolybdophosphoric acid.

Extraction of respiratory lipoquinones and polar lipids. Respiratory lipoquinones and polar lipids were extracted from $100 \mathrm{mg}$ freeze-dried cell material using the twostage method described by Tindall $(1990 \mathrm{a}, \mathrm{b})$. Respiratory quinones were extracted using methanol/hexane (Tindall, $1990 \mathrm{a}, \mathrm{b})$ and the polar lipids were extracted by adjusting the remaining methanol $/ 0 \cdot 3 \%$ aqueous $\mathrm{NaCl}$ phase (containing the cell debris) to give a choroform $/$ methanol $/ 0 \cdot 3 \%$ aqueous $\mathrm{NaCl}$ mixture $(1: 2: 0 \cdot 8$, by vol.). The extraction solvent was stirred overnight and the cell debris pelleted by centrifugation. Polar lipids were recovered into the chloroform phase by adjusting the chloroform/methanol $/ 0 \cdot 3 \%$ aqueous $\mathrm{NaCl}$ mixture to a ratio of $1: 1: 0 \cdot 9$ (by vol.).

Analysis of respiratory lipoquinones. Respiratory lipoquinones were separated into their different classes (menaquinones and ubiquinones) by TLC on silica gel (art. no. 805023; Macherey-Nagel), using hexane/tert-butylmethylether $(9: 1, \mathrm{v} / \mathrm{v})$ as solvent. UV-absorbing bands corresponding to menaquinones or ubiquinones were removed from the plate and further analysed by HPLC. This step was carried out with LDC analytical HPLC equipment (Thermo Separation Products) fitted with a reverse-phase column $\left(2 \mathrm{~mm} \times 125 \mathrm{~mm}, 3 \mu \mathrm{m}, \mathrm{RP}_{18} ;\right.$ Macherey-Nagel), using methanol as the eluant. Respiratory lipoquinones were detected at $269 \mathrm{~nm}$.

Analysis of polar lipids. Polar lipids were separated by twodimensional, silica-gel TLC (art. no. 818135; MachereyNagel). The first direction was developed in chloroform/ methanol/water $(65: 25: 4$, by vol.) and the second in chloroform/methanol/acetic acid/water $(80: 12: 15: 4$, by vol.). Total lipid material and specific functional groups were detected using dodecamolybdophosphoric acid (total lipids), Zinzadze reagent (phosphate), ninhydrin (free amino groups), periodate Schiff ( $\alpha$-glycols), Dragendorff (quaternary nitrogen) and anisaldehyde-sulfuric acid (glycolipids).

DNA base composition and 16S rDNA sequence analysis. DNA base composition and 16S rDNA sequence analysis was carried out at the DSMZ (Deutsche Sammlung von Mikroorganismen und Zellkulturen, Braunschweig, Germany). The $\mathrm{G}+\mathrm{C}$ content of the DNA was determined by HPLC according to Mesbah et al. (1989). Genomic DNA extraction, PCR-mediated amplification and purification of the PCR products were carried out as described previously (Rainey et al., 1996). Purified PCR products were sequenced using the ABI PRISM Dye Terminator Cycle Sequencing Ready Reaction Kit (Applied Biosystems), as directed in the manufacturer's protocol. Sequence reactions were electrophoresed using the Applied Biosystems 373A DNA sequencer. Sequences were aligned taking secondary structure into consideration. Sequence similarities were calculated using the maximum number of positions possible and covered the region at positions 23-1482 (Escherichia coli numbering), which coincided with positions 18-1415 when Halobacterium halobium sequence X03407 was used as the reference secondary structure. Sequences were not masked.
The 16S rDNA dendrogram was inferred using programs from the PHYLIP package. Similarity values were used to calculate distances using DNADIST; the programs FITCH and DNAML were used to infer the 16S rDNA dendrogram. No attempt was made to test the significance of the branching order (based on the sequence data alone) of all taxa present, because of the presence of long pendant edges and several short internal edges in the dendrogram. Under such conditions it is not always possible to resolve the branching order unambiguously.

Sequences used for the analysis were as follows: strain AX$2^{\mathrm{T}}$, AF071880; Halobacterium cutirubrum, K02971; Halococcus morrhuae (ATCC 17082 ${ }^{\mathrm{T}}$ ) X72588; Halococcus salifodinae $\left(\mathrm{B} 1 \mathrm{p}^{\mathrm{T}}\right), \mathrm{Z28387}$; Haloarcula vallismortis (IFO $\left.14741^{\mathrm{T}}\right)$, D50851; Haloarcula mukohataei $\left(\arg -2^{\mathrm{T}}=\mathrm{JCM}\right.$ 9738 ${ }^{\mathrm{T}}$ ), D50850; Natronomonas pharaonis (JCM 8858 ${ }^{\mathrm{T}}$ ), D87971; Halorubrum saccharovorum (JCM 8865'T), U17364; Halorubrum vacuolatum (JCM 9060 ${ }^{\mathrm{T}}$ ), D87972; Natronobacterium gregoryi (NCIMB 2189 $\left.{ }^{\mathrm{T}}\right)$, D87970; Natronococcus amylolyticus $\left(\mathrm{Ah}-36^{\mathrm{T}}\right)$, D43628; Natronococcus occultus (NCIMB 2192 ${ }^{\mathrm{T}}$ ), Z28378; Natrialba magadii (NCIMB $\left.2190^{\mathrm{T}}\right), \mathrm{X} 72495$; Natrialba asiatica $\left(172 \mathrm{P} 1^{\mathrm{T}}\right), \mathrm{D} 14123$; and Haloferax volcanii, K00421.

\section{RESULTS}

\section{Morphology}

The cells exhibited anything from irregular coccoid or ellipsoid to apparently triangular, club-shaped or rodshaped forms (Fig. 1). Hence, they were extremely pleomorphic. However, the proportion of rod-shaped cells was highest in younger cultures. Rod-shaped cells were $2-10 \times 0 \cdot 5-1 \mu \mathrm{m}$ in size, ellipsoid cells were $1-2 \times 1 \mu \mathrm{m}$ and spherical cells had a diameter of approximately $1 \mu \mathrm{m}$. The organisms were motile and had a single flagellum 3-5 $\mu \mathrm{m}$ long. The cells stained Gram-negative and endospores were not produced. Red colonies were formed on agar plates. The colonies were circular, with diameters ranging from 0.5 to $3.5 \mathrm{~mm}$, depending on age. They were convex with an entire margin and a shiny surface.

\section{Physiological and biochemical characterization}

Strain $\mathrm{AX}-2^{\mathrm{T}}$ was capable of growing over a wide range of salinities in both complex (Tris 10) and defined (Tris 9) medium. Growth was possible at $\mathrm{NaCl}$

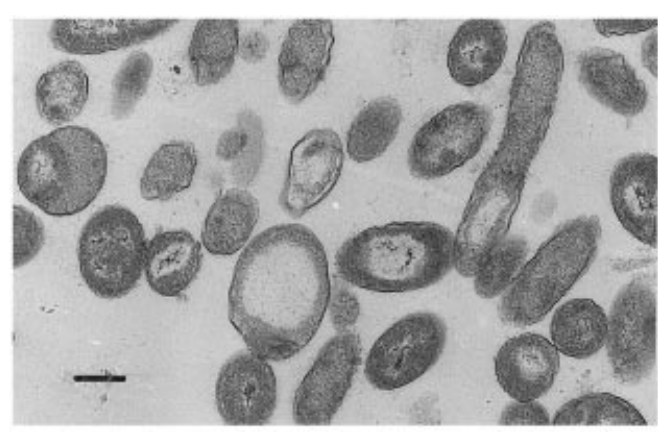

Fig. 1. Transmission electron micrograph showing pleomorphic cells of strain AX-2 ${ }^{\top}$. Bar, $1 \mu \mathrm{m}$. 


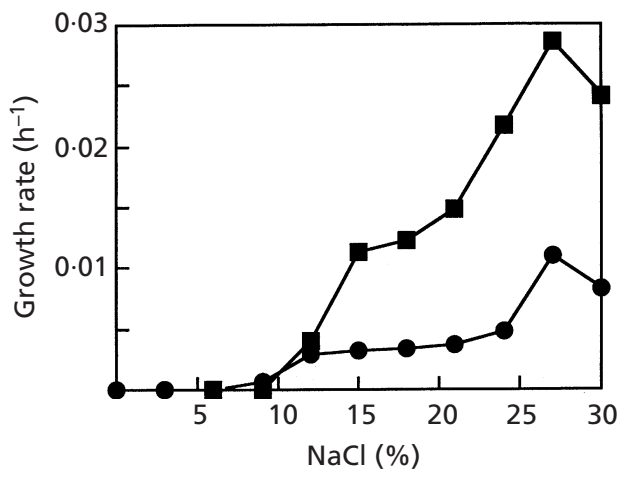

Fig. 2. Growth of strain $A X-2^{\top}$ at different $\mathrm{NaCl}$ concentrations. The organisms were grown at $30{ }^{\circ} \mathrm{C}$ in either complex medium (Tris $10, \square$ ) or defined medium (Tris 9, - containing $0.2 \%$ (w/v) glucose.

concentrations ranging from $9 \%$ in defined medium and $12 \%$ in complex medium to the point of saturation (approx. $30 \% \mathrm{NaCl}$ ) at $30{ }^{\circ} \mathrm{C}$ (Fig. 2). In both media, optimal growth was at $27 \% \mathrm{NaCl}$. However, because of evaporation the salinity of the cultures increased $1-2 \%$ during growth. When grown at $30{ }^{\circ} \mathrm{C}$ and in complex medium containing $27 \% \mathrm{NaCl}$, the $\mathrm{MgSO}_{4}$ range supporting growth was $0.05-20 \%(2-800 \mathrm{mM})$. There was no growth at $25 \% \mathrm{MgSO}_{4}$. The $\mathrm{MgSO}_{4}$ content of the medium had only minor effects on the growth rates of the cultures, but the lag phase was extended for several weeks at high $\mathrm{MgSO}_{4}$ concentrations. In the presence of $27 \% \mathrm{NaCl}$, the organisms grew at temperatures between 17 and $55^{\circ} \mathrm{C}$, with optimal growth occurring at $50{ }^{\circ} \mathrm{C}$. The strain could grow over a $\mathrm{pH}$ range of $5.5-8.5$ at $30{ }^{\circ} \mathrm{C}$ in presence of $27 \% \mathrm{NaCl}$; the optimal $\mathrm{pH}$ for growth was between 6.7 and $7 \cdot 1$.

The isolate was tested for growth on various carbon sources in both complex and defined medium. Only a very few sugars, such as glucose, xylose and fructose, supported growth. None of the tested organic acids, amino acids, alcohols, glycogen, peptone, yeast extract or starch stimulated growth. Acid was produced when the strain was grown on sugars. The strain grew in defined anaerobic medium (AM-2) by fermenting glucose. However, in the presence of sulfur, growth was stimulated, with concomitant production of hydrogen sulfide, perhaps in a facilitated fermentation manner like that suggested by Widdel \& Pfennig (1992). No clear evidence of growth was found when either acetate or ethanol was used as a non-fermentable substrate in combination with $\mathrm{S}^{\mathrm{o}}, \mathrm{SO}_{4}$ or $\mathrm{S}_{2} \mathrm{O}_{3}$ as the potential electron acceptor. Nitrate, however, was unambiguously reduced to nitrite in anaerobic incubations with glucose, but was not observed to stimulate growth.

The isolate was catalase- and oxidase-positive, lysed in distilled water and did not require amino acids for growth. The strain was susceptible to bacitracin and novobiocin but resistant to ampicillin, carbenicillin,
Table 1. Biochemical and physiological features of strain AX-2 $2^{\top}$

All tests were performed at salinities of at least $20 \% \mathrm{NaCl}$. + , Positive; - , negative; PHB, poly- $\beta$-hydroxybutyrate.

\begin{tabular}{|c|c|}
\hline Characteristic & $\mathbf{A X}-\mathbf{2}^{\mathrm{T}}$ \\
\hline Gram reaction & - \\
\hline Fermentative growth & + \\
\hline Amino acid requirement & - \\
\hline $\mathrm{Mg}^{2+}$ requirement $(\mathrm{mM})$ & 2 \\
\hline Temp. range for growth $\left({ }^{\circ} \mathrm{C}\right)$ & $\begin{array}{c}17-55 \\
\text { (optimum 50) }\end{array}$ \\
\hline $\mathrm{pH}$ range for growth & $\begin{array}{c}5 \cdot 5-8 \cdot 5 \\
\text { (optimum } 6 \cdot 7-7 \cdot 1 \text { ) }\end{array}$ \\
\hline $\mathrm{NaCl}$ range for growth $(\%)$ & $\begin{array}{c}\text { 9-30 } \\
\text { (optimum 27) }\end{array}$ \\
\hline $\mathrm{MgSO}_{4}$ range for growth $(\%)$ & $0 \cdot 05-20$ \\
\hline Lysis in water & + \\
\hline Catalase & + \\
\hline Oxidase & + \\
\hline Urease & - \\
\hline Arginine dihydrolase & - \\
\hline Lysine decarboxylase & - \\
\hline Ornithine decarboxylase & - \\
\hline Tryptophan deaminase & - \\
\hline Utilization of citrate (Simmons' citrate) & - \\
\hline \multicolumn{2}{|l|}{ Hydrolysis of: } \\
\hline Aesculin & + \\
\hline Gelatin & - \\
\hline Starch & - \\
\hline Carbohydrates & + \\
\hline Methyl red & - \\
\hline Voges-Proskauer & - \\
\hline Acid production from carbohydrates & + \\
\hline Gas production from carbohydrates & - \\
\hline PHB production & + \\
\hline Indole production & - \\
\hline $\mathrm{NO}_{3}^{-}$reduction & + \\
\hline $\mathrm{H}_{2} \mathrm{~S}$ production & + \\
\hline
\end{tabular}

chloramphenicol, erythromycin, gentamicin, kanamycin, nalidixic acid, neomycin, penicillin, polymyxins, rifampicin, streptomycin and tetracycline. Several aerobic, extremely halophilic members of the Archaea have been shown to produce high amounts of PHB when grown under C-rich and N-limited conditions (Fernandez-Castillo et al., 1986). Therefore, strain $\mathrm{AX}-2^{\mathrm{T}}$ was tested and found positive for $\mathrm{PHB}$ production when cultured in PHB medium. The organism was tested for the production of various enzymes. Arginine dihydrolase was negative. In the absence of this enzyme, the mechanism supporting anaerobic growth on arginine, as described by Hartmann et al. (1980), cannot operate. An API ZYM test (25200; bioMérieux) showed that the strain was positive for esterase, lipase and glucosidase. (See Table 1 for details of additional biochemical characteristics.) 


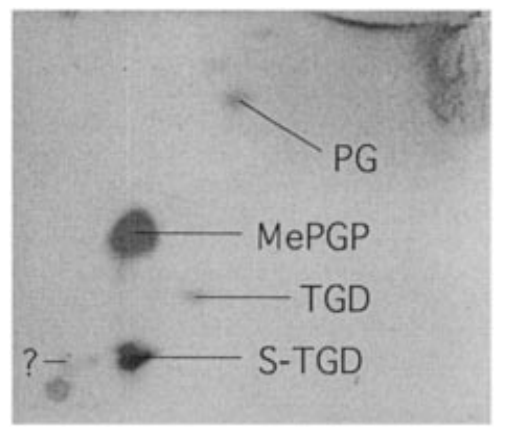

Fig. 3. Polar lipid composition of Halorhabdus utahensis separated by two-dimensional TLC (for conditions, see Methods). PG, phosphatidyl glycerol; MePGP, methylatedphosphatidyl glycerophosphate; TGD, triglycosyl glycolipid; STGD, sulfated triglycosyl glycolipid. Direction of development: first dimension, horizontal; second dimension, vertical. The origin is in the bottom left-hand corner.

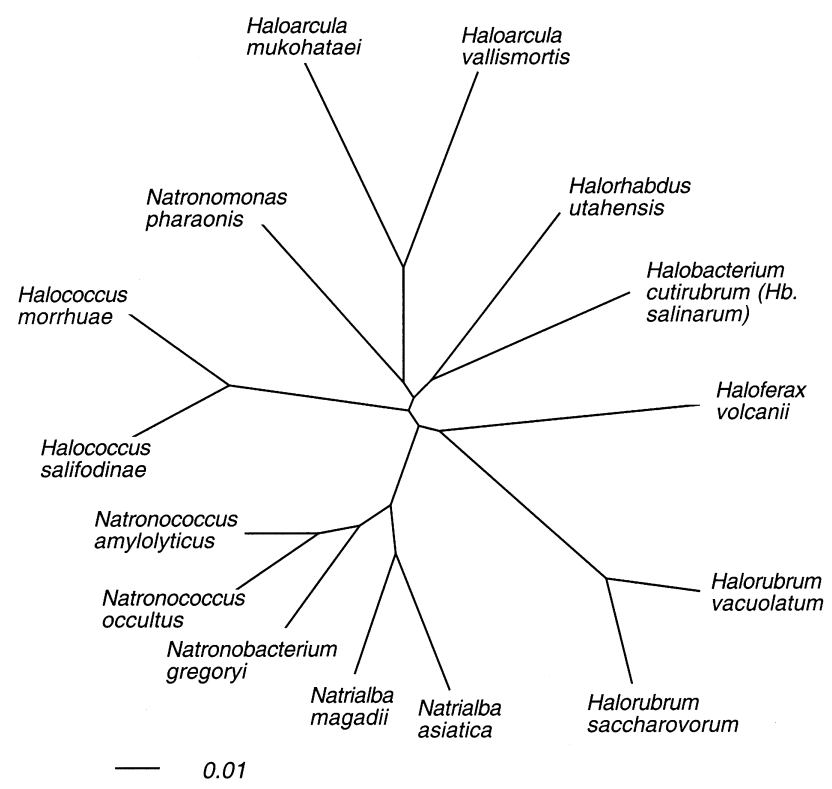

Fig. 4. Unrooted phylogenetic tree showing the relationship between strain $A X-2^{\top}$ and various members of the family Halobacteriaceae. Bar, 0.01 changes per nucleotide.

\section{Ether lipids, quinones and polar lipids}

Examination of the lipid fraction after hydrolysis of intact cells indicated that isoprenoid ether lipids were present, a feature unique to members of the Archaea. The ether lipids comprised only diether lipids, tetraether lipids being absent. The major diether lipids present were the diphytanyl derivatives $\left(\mathrm{C}_{20}, \mathrm{C}_{20}\right)$. Menaquinones were the only respiratory lipoquinones present and comprised MK-8 and MK-8(VIII- $\left.\mathrm{H}_{2}\right)$. As shown in Fig. 3, the major polar lipids present were PG, MePGP, a TGD and an S-TGD. Furthermore, small amounts of an unknown polar lipid were produced. Nevertheless, the presence of diether lipids, MK-8 and MK-8(VIII- $\left.\mathrm{H}_{2}\right)$ coupled with the presence of PG and Me-PGP are characteristic features of the monophyletic taxon defined by the family Halobacteriaceae.

\section{DNA base composition and phylogeny}

The $\mathrm{G}+\mathrm{C}$ content of the DNA of strain $\mathrm{AX}-2^{\mathrm{T}}$ was $64 \mathrm{~mol} \%$. Approximately $95 \%$ (1421 bases) of the $16 \mathrm{~S}$ rRNA sequence was determined. Comparison of the sequence with members of the family Halobacteriaceae revealed that strain $\mathrm{AX}-2^{\mathrm{T}}$ was distantly related to the other genera investigated. Apparently, Halobacterium cutirubrum (Halobacterium salinarum) is the closest relative of strain $\mathrm{AX}-2^{\mathrm{T}}$, having a sequence similarity value of $90.5 \%$. However, the similarity values were almost identical for several aerobic, extremely halophilic members of the Archaea representing various genera, e.g. Natronomonas pharaonis (89.7\%), Natronobacterium gregoryi $(88.8 \%)$ and Natrialba asiatica $(88 \cdot 3 \%)$. Thus, strain $\mathrm{AX}-2^{\mathrm{T}}$ represents a new species within a new genus of the family Halobacteriaceae. The unrooted phylogenetic tree in Fig. 4 shows the relationship between strain $\mathrm{AX}-2^{\mathrm{T}}$ and the representatives of the family Halobacteriaceae.

\section{DISCUSSION}

Strain $\mathrm{AX}-2^{\mathrm{T}}$ was isolated from sediment of the hypersaline Great Salt Lake, UT, USA. On the basis of its pigmentation, pleomorphic nature, $\mathrm{NaCl}$-dependent growth, antibiotic susceptibility, chemical composition and $16 \mathrm{~S}$ rDNA sequence, strain $\mathrm{AX}-2^{\mathrm{T}}$ was identified as a member of the family Halobacteriaceae. Developments within the taxonomy of the family Halobacteriaceae have seen a change from an emphasis on morphology and physiology (1930-1975) to the distinction of various genera on the basis of lipid composition (1978-1992). Since 1992 the inclusion of sequence data, particularly that from the $16 \mathrm{~S}$ rDNA, has become of prime importance in modern taxonomy. Fry et al. (1991) and Devereux et al. (1990) have tried to lay down guidelines for the delineation of genera, using $16 \mathrm{~S}$ rDNA similarity values. In practice, however, delineation based on 16S rDNA sequences alone has ranged from setting fixed similarity values to taking different evolutionary depths and evolutionary rates into consideration. Therefore, it seems beneficial to adopt a polythetic system in which the resolution of various data sets (phenotypic and genotypic) is assessed when the taxonomic status of a strain is inferred. The $16 \mathrm{~S}$ rDNA similarity values of strain $\mathrm{AX}-2^{\mathrm{T}}$ indicate that this is a new species within a new genus. However, it is also possible to distinguish this genus from all other described genera within the family Halobacteriaceae by evaluating the phenotypic data; however, because the species is monotypic, little can be said about the future features differentiating species within the genus. Strain $\mathrm{AX}-2^{\mathrm{T}}$ is unique within the family Halobacteriaceae, in terms of its inability to utilize complex substrates for growth (i.e. yeast extract or peptone) and its lipid composition. Thus, the 
Table 2. Distinction of genera belonging to the family Halobacteriaceae, based on phenotypic properties

Data were obtained from Torreblanca et al. (1986), Ihara et al. (1997), Emerson et al. (1994), Grant \& Larsen (1989), Tindall et al. (1984), Kamekura \& Dyall-Smith (1995), Oren et al. (1995), McGenity \& Grant (1995) and Soliman \& Trüper (1982). Abbreviations: Pleom., pleomorphic; PG, phosphatidyl glycerol; PGP, phosphatidyl glycerophosphate; Me-PGP, methylatedphosphatidyl glycerophosphate; PGS, phosphatidyl glycerosulfate; DGD, diglycosyl diether; S-DGD, sulfated diglycosyl diether; $\mathrm{S}_{2}$-DGD, bis-sulfated diglycosyl diether; TGD, triglycosyl diether; S-TGD, sulfated triglycosyl diether; S-TeGD, sulfated tetraglycosyl diether. No attempt has been made to differentiate between the different structural forms of S-DGD or TGD because this is not significant in the differentiation of strain $\mathrm{AX}-2^{\mathrm{T}}$, which represents the genus Halorhabdus.

\begin{tabular}{|c|c|c|c|c|c|c|c|c|c|c|c|}
\hline Phenotypic property & Halorhabdus & Haloarcula & Halobacterium & Halococcus & Haloferax & Halorubrum & Halobaculum & Natrialba & Natronobacterium & Natronococcus & Natronomonas \\
\hline Cell shape & Pleom. rods & Pleom. rods & Rods & Cocci & Pleom. rods & $\begin{array}{l}\text { Pleom. rods } \\
\text { or rods }\end{array}$ & Rods & Rods & Rods & Cocci & Rods \\
\hline $\begin{array}{l}\mathrm{Mg}^{2+} \text { required for } \\
\text { growth }(\mathrm{mM})^{*}\end{array}$ & 2 & 3 & 5 & $<1$ & 5 & 5 & approx. 100 & 0 & $<10$ & $<1$ & $<10$ \\
\hline \multicolumn{12}{|l|}{ Polar lipids: } \\
\hline PG & + & + & + & + & + & + & + & + & + & + & + \\
\hline $\mathrm{Me}-\mathrm{PGP} \dagger$ & + & + & + & + & + & + & + & + & + & + & + \\
\hline Cyclic-PGP & - & - & - & - & - & - & - & - & - & + & - \\
\hline PGS & - & + & + & - & - & + & - & - & - & - & - \\
\hline DGD & - & + & - & - & + & - & - & - & - & - & - \\
\hline S-DGD & - & - & - & + & + & + & + & - & - & - & - \\
\hline $\mathrm{S}_{2}$-DGD & - & - & - & - & - & - & - & + & - & - & - \\
\hline TGD & + & + & + & + & - & - & - & - & - & - & - \\
\hline S-TGD & + & - & + & - & - & - & - & - & - & - & - \\
\hline S-TeGD & - & - & + & - & - & - & - & - & - & - & - \\
\hline
\end{tabular}

* The amount of $\mathrm{Mg}^{2+}$ required for growth represents the lowest value found for a member of the genus.

$\dagger$ Although the older literature refers to the presence of PGP in all members of the family Halobacteriaceae, it is now known that this compound is in fact methylated (Me-PGP).

creation of a new genus, Halorhabdus, within which Halorhabdus utahensis is the type species (of which strain $\mathrm{AX}-2^{\mathrm{T}}$ is the type strain), can be justified.

\section{Physiology}

Strain $\mathrm{AX}-2^{\mathrm{T}}$ had an extremely high salinity optimum of $27 \%(\mathrm{w} / \mathrm{v}) \mathrm{NaCl}$ for growth. Although it is not unusually high - most extremely halophilic archaea are reported to grow optimally at $20-26 \%(\mathrm{w} / \mathrm{v}) \mathrm{NaCl}$ (Grant \& Larsen, 1989) - it seems to be the highest reported salinity optimum of any living organism. However, it is pertinent to be cautious concerning conclusions based on these data since the range of salinity supporting growth, as well as the optimum salinity, is highly dependent on other growth parameters, most importantly temperature and nutrition (Forsyth \& Kushner, 1970).

\section{Chemotaxonomy}

The ether lipid, respiratory lipoquinone and polar lipid composition of strain $\mathrm{AX}-2^{\mathrm{T}}$ clearly indicated that it was a member of the monophyletic group within the Archaea defined by the family Halobacteriaceae. However, a number of features distinguished strain $\mathrm{AX}-2^{\mathrm{T}}$ from other, currently known taxa within this family (see Table 2). In particular, the presence of S-TGD and the absence of PGS were unique features of strain AX$2^{\mathrm{T}}$. Members of the family Halobacteriaceae can be divided into a number of chemical groups. These include one group in which only phospholipids are present and another in which phospholipids and glycolipids are present. The second of these groups may be further divided into a group in which PGS is present and another in which PGS is absent. Furthermore, a distinction may be made between those organisms in which the predominant glycolipids are either TGDs, S-DGDs or S-TGDs. To date, members of the genus Halobacterium constitute the only known group of aerobic, extremely halophilic microorganisms within the Archaea which produce an STGD, like strain $\mathrm{AX}-2^{\mathrm{T}}$. However, members of the genus Halobacterium also produce a TGD (and/or its sulfated derivative) and PGS, unlike strain AX-2 $2^{\mathrm{T}}$ (which synthesizes neither of these compounds). Thus, strain $\mathrm{AX}-2^{\mathrm{T}}$ may be distinguished unambiguously from all other known members of the family Halobacteriaceae.

\section{Taxonomy}

On the basis of the phenotypic (biochemical, physiological, morphological and chemical) and genotypic (16S rDNA sequence and $\mathrm{G}+\mathrm{C}$ ) data, strain $\mathrm{AX}-2^{\mathrm{T}}$ may be considered to be a member of a new taxon within the family Halobacteriaceae for which we propose the name Halorhabdus utahensis gen. nov., sp. nov.

\section{Description of Halorhabdus Wainø, Tindall and Ingvorsen gen. nov.}

Halorhabdus [Ha.lo.rhab'dus. Gr. n. hals salt; Gr. n. rhabdos rod or stick; M.L. masc. n. Halorhabdus salt (-loving) rod]. 
Cells are extremely pleomorphic although most are rod-shaped. Rod-shaped cells are $0 \cdot 5-1 \mu \mathrm{m}$ wide and $2-10 \mu \mathrm{m}$ long. Motile by a single flagellum. Colonies are red and circular with an entire margin and a shiny surface. Extremely halophilic and lyse in water. Grows at $9-30 \%(1 \cdot 5-5 \cdot 1 \mathrm{M}) \mathrm{NaCl}$; optimum growth at $27 \%$ $(4.6 \mathrm{M}) \mathrm{NaCl}$. Grows between 0.05 and $20 \% \mathrm{MgSO}_{4}$ $(2-800 \mathrm{mM})$ in the presence of $27 \% \mathrm{NaCl}$. Grows at temperatures from 17 to $55{ }^{\circ} \mathrm{C}$, with an optimum at $50{ }^{\circ} \mathrm{C}$. The $\mathrm{pH}$ range for growth is $5 \cdot 5-8 \cdot 5$, with an optimum between $6 \cdot 7$ and $7 \cdot 1$. Ferments glucose. Sulfur stimulates fermentative growth. Amino acids are not required for growth; grows under aerobic or anaerobic conditions in defined media. Gram-negative cell wall. Catalase- and oxidase-positive. Amino acids are not decarboxylated or deaminated. Produces $\beta$ glucosidase and lipase. Does not produce $\beta$-galactosidase. Hydrogen sulfide is produced. Methyl red and Voges-Proskauer tests are negative. No utilization of citrate (Simmons' citrate). No production of indole. PHB is produced. Acid is produced from carbohydrates. Cells are resistant to ampicillin, carbenicillin, chloramphenicol, erythromycin, gentamicin, kanamycin, nalidixic acid, neomycin, penicillin, polymyxins, rifampicin, streptomycin and tetracycline but susceptible to bacitracin and novobiocin. A limited number of organic substrates are used for growth. The $\mathrm{G}+\mathrm{C}$ content of the only species in the genus is $64 \mathrm{~mol} \%$. Ether lipids are diphytanyl derivatives. MK8 and MK-8(VIII- $\left.\mathrm{H}_{2}\right)$ are the only respiratory lipoquinones present. The polar lipids present are PG, MePGP, TGD, S-TGD and an unknown component. PGS is absent. The type species of the genus is Halorhabdus utahensis sp. nov.

\section{Description of Halorhabdus utahensis Wainø, Tindall and Ingvorsen sp. nov.}

Halorhabdus utahensis (u'tah.ensis. M.L. n. pertaining to the state of Utah, USA, where the strain was isolated).

The description of Halorhabdus utahensis is identical to that given above for the genus, with the following additions. The following substrates $(0 \cdot 2 \%, \mathrm{w} / \mathrm{v})$ are utilized for growth: glucose, xylose and fructose. No growth on amylose, arginine, D-arabinose, Dgalactose, lactose, maltose, sucrose, Na-acetate, Nacitrate, Na-formiate, Na-D-glucuronate, Na-lactate, Na-pyruvate, $N$-acetyl-glucosamine, L-alanine, betaine, L-lysine, phenylalanine, L-proline, L-serine, acetamide, ethanol, glycerol, methanol, D-sorbitol, glycogen, peptone, yeast extract, starch, casein, gelatin or Tween 80. Aesculin is hydrolysed. No hydrolysis of gelatin or starch. Does not produce protease or urease. Nitrate is reduced to nitrite. Does not produce arginine dihydrolase, lysine decarboxylase, ornithine decarboxylase or tryptophan deaminase. The $\mathrm{G}+\mathrm{C}$ content of the DNA of the only strain known in the species is $64 \mathrm{~mol} \%$. The type strain, strain $\mathrm{AX}-2^{\mathrm{T}}$, isolated from Great Salt Lake, UT, USA, has been deposited in the Deutsche Sammlung von Mikro- organismen und Zellkulturen GmbH (Braunschweig, Germany) as strain DSM $12940^{\mathrm{T}}$.

\section{ACKNOWLEDGEMENTS}

We would like to thank Tove Wiegers and Jacques Chevallier for excellent technical assistance and Susanne Baumgart (GBF, Braunschweig, Germany) for assistance with the 16S rDNA sequence data. This work was supported by the Danish Natural Science Research Foundation (grant 523.33353) to K.I. and M.W.

\section{REFERENCES}

Balch, W. E., Fox, G. E., Magrum, L. J., Woese, C. R. \& Wolfe, R. S. (1979). Methanogens: re-evaluation of a unique biological group. Microbiol Rev 43, 260-296.

Denner, E. B. M., McGenity, T. J., Busse, H.-J., Grant, W. D., Wanner, G. \& Stan-Lotter, H. (1994). Halococcus salifodinae sp. nov., an archaeal isolate from an Austrian salt mine. Int J Syst Bacteriol 44, 774-780.

Devereux, R., He, S.-H., Doyle, C. L., Orkland, S., Stahl, D. A., LeGall, J. \& Whitman, W. B. (1990). Diversity and origin of Desulfovibrio species: phylogenetic definition of a family. J Bacteriol 172, 3609-3619.

Cord-Ruwisch, R. (1985). A quick method for the determination of dissolved and precipitated sulfides in cultures of sulfatereducing bacteria. J Microbiol Methods 4, 33-36.

Dussault, H.P. (1955). An improved technique for staining halophilic bacteria. J Bacteriol 70, 484-485.

Eikel, I. \& Sprott, G. D. (1992). Identification of degradation artifacts formed upon treatment of hydroxydiether lipids from methanogens with methanolic $\mathrm{HCl}$. Can J Microbiol 38, 764-768.

Emmerson, D., Chauhan, S., Oriel, P. \& Breznak, J. A. (1994). Haloferax sp. D1227, a halophilic Archaeon capable of growth on aromatic compounds. Arch Microbiol 161, 445-452.

Fernandez-Castillo, R., Rodriguez-Valera, F., Gonzalez-Ramos, J. \& Ruiz-Berraquero, F. (1986). Accumulation of $\operatorname{poly}(\beta$ hydroxybutyrate) by halobacteria. Appl Environ Microbiol 51, 214-216.

Forsyth, M. P. \& Kushner, D. J. (1970). Nutrition and distribution of salt response in populations of moderately halophilic bacteria. Can J Microbiol 16, 253-261.

Franzmann, P. D., Stackebrandt, E., Sanderson, K., Volkman, J. K., Cameron, D. E., Stevenson, P. L., McMeekin, T. A. \& Burton, H. R. (1988). Halobacterium lacusprofundi sp. nov., a halophilic bacterium isolated from Deep Lake, Antarctica. Syst Appl Microbiol 11, 20-27.

Fry, N. K., Warwick, S., Saunders, N. A. \& Embley, T. M. (1991). The use of 16S rRNA analyses to investigate the phylogeny of the family Legionellaceae. J Gen Microbiol 137, 1215-1222.

Gerhardt, P., Murray, R. G. E., Costilow, R. N., Nester, E. W., Wood, W. A., Krieg, N. R. \& Philips, G. B. (1981). Manual of Methods for General Bacteriology. Washington, DC: American Society for Microbiology.

Grant, W. D. \& Larsen, H. (1989). Extremely halophilic archaeobacteria order Halobacteriales ord. nov. In Bergey's Manual of Systematic Bacteriology, vol. 3, pp. 2216-2233. Edited by J. T. Staley, M. P. Bryant, N. Pfennig \& J. G. Holt. Baltimore: Williams \& Wilkins.

Hartmann, R., Sickinger, H.-D. \& Oesterhelt, D. (1980). Anaerobic growth of halobacteria. Proc Natl Acad Sci USA 77, 3821-3825. 
Ihara, K., Watanabe, S. \& Tamura, T. (1997). Haloarcula argentinensis sp. nov. and Haloarcula mukohataei sp. nov., two new extremely halophilic archaea collected in Argentina. Int $J$ Syst Bacteriol 47, 73-77.

Ingvorsen, K. \& Jørgensen, B. B. (1984). Kinetics of sulfate uptake by freshwater and marine species of Desulfovibrio. Arch Microbiol 139, 61-66.

Juez, G., Rodriguez-Valera, F., Ventosa, A. \& Kushner, D. J. (1986). Haloarcula hispanica spec. nov. and Haloferax gibbonsii spec. nov., two new species of extremely halophilic archaebacteria. Syst Appl Microbiol 8, 75-79.

Kamekura, M. \& Dyall-Smith, M. L. (1995). Taxonomy of the family Halobacteriaceae and the description of the two new genera Halorubrobacterium and Natrialba. J Gen Appl Microbiol 41, 333-350.

Kobayashi, T., Kanai, H., Hayashi, T., Akiba, T., Akaboshi, R. \& Horikoshi, K. (1992). Haloalkaliphilic maltotriose-forming $\alpha$ amylase from the archaebacterium Natronococcus sp. Strain Ah-36. J Bacteriol 174, 3439-3444.

Lillo, J. C. \& Rodriguez-Valera, F. (1990). Effects of culture conditions on poly $(\beta$-hydroxybutyric acid) production by Haloferax mediterranei. Appl Environ Microbiol 56, 2517-2521.

McGenity, T. J. \& Grant, W. D. (1995). Transfer of Halobacterium saccharovorum, Halobacterium sodomense, Halobacterium trapanicum NRC 34021 and Halobacterium lacusprofundi to the genus Halorubrum gen. nov., as Halorubrum saccharovorum comb. nov., Halorubrum sodomense comb. nov., Halorubrum trapanicum comb. nov., and Halorubrum lacusprofundi comb. nov. Syst Appl Microbiol 18, 237-243.

Mesbah, M., Premachandran, U. \& Whitman, W. B. (1989). Precise measurement of the $\mathrm{G}+\mathrm{C}$ content of deoxyribonucleic acid by high-performance liquid chromatography. Int J Syst Bacteriol 39, 159-167.

Norton, C. F., McGenity, T. J. \& Grant, W. D. (1993). Archaeal halophiles (halobacteria) from two British salt mines. $J$ Gen Microbiol 139, 1077-1081.

Nuttall, S. D. \& Dyall-Smith, M. L. (1993). Ch2, a novel halophilic archaeon from an Australian solar saltern. Int $J$ Syst Bacteriol 43, 729-734.

Oren, A., Gurevich, P., Gemmell, R. T. \& Teske, A. (1995). Halobaculum gomorrense gen. nov., sp. nov., a novel extremely halophilic archaeon from the Dead Sea. Int J Syst Bacteriol 45, 747-754.

Rainey, F. A., Ward-Rainey, N., Kroppenstedt, R. M. \& Stackebrandt, E. (1996). The genus Nocardiopsis represents a phylogenetically coherent taxon and a distinct actinomycete lineage; proposal of Nocardiopsaceae fam. nov. Int J Syst Bacteriol 46, 1088-1092.

Skerman, V. B. D. (1967). A Guide to the Identification of the Genera of Bacteria, 2nd edn. Baltimore: Williams \& Wilkins.

Soliman, G. S. H. \& Trüper, H. G. (1982). Halobacterium pharaonis sp. nov., a new, extremely haloalkaliphilic archaebacterium with low magnesium requirement. $\mathrm{Zbl}$ Bakteriol $\mathrm{Hyg}, \mathrm{I} \mathrm{Abt}$ Orig C 3, 318-329.

Tindall, B. J. (1990a). A comparative study of the lipid composition of Halobacterium saccharovorum from various sources. Syst Appl Microbiol 13, 128-130.

Tindall, B. J. (1990b). Lipid composition of Halobacterium lacusprofundi. FEMS Microbiol Lett 66, 199-202.

Tindall, B. J., Ross, H. N. M. \& Grant, W. D. (1984). Natronobacterium gen. nov. and Natronococcus gen. nov., two new genera of haloalkalophilic archaebacteria. Syst Appl Microbiol 5, 41-57.

Torreblanca, M., Rodriguez-Valera, F., Juez, G., Ventosa, A., Kamekura, M. \& Kates, M. (1986). Classification of nonalkaliphilic halobacteria based on numerical taxonomy and polar lipid composition, and description of Haloarcula gen. nov. and Haloferax gen. nov. Syst Appl Microbiol 8, 89-99.

Wainø, M., Tindall, B. J., Schumann, P. \& Ingvorsen, K. (1999). Gracilibacillus gen. nov., with description of Gracilibacillus halotolerans gen. nov., sp. nov.; transfer of Bacillus dipsosauri to Gracilibacillus dipsosauri comb. nov., and Bacillus salexigens to the genus Salibacillus gen. nov., as Salibacillus salexigens comb. nov. Int J Syst Bacteriol 49, 821-831.

Widdel, F. \& Pfennig, N. (1992). The genus Desulfuromonas and other gram-negative sulfur-reducing eubacteria. In The Prokaryotes, 2nd edn, vol. 4, pp. 3380-3389. Edited by A. Balows, H. G. Trüper, M. Dworkin, W. Harder \& K.-H. Schleifer. New York: Springer.

Zvyagintseva, I. S. \& Tarasov, A. L. (1987). Extreme halophilic bacteria from saline soils. Microbiology (English translation of Mikrobiologiya) 56, 664-668. 